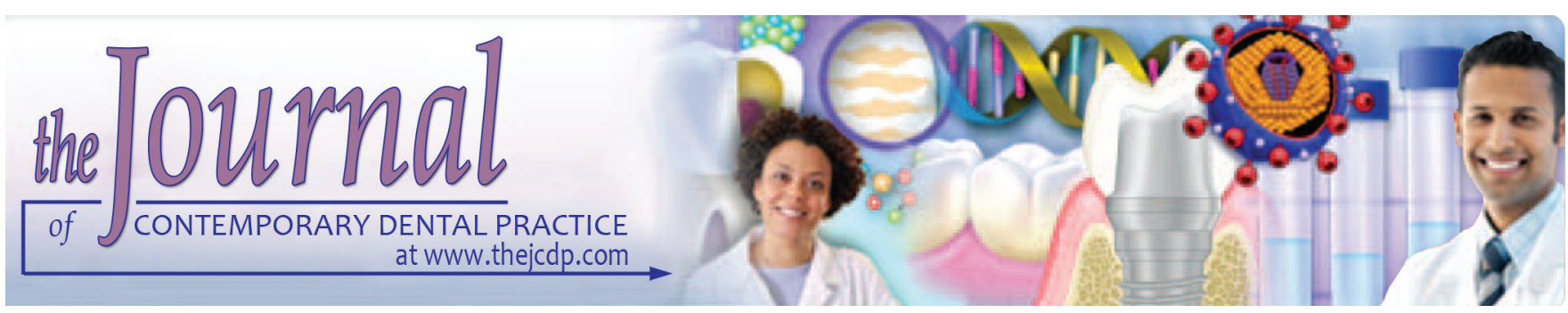

\title{
Assessment of the Influence of Meal Type on Fluoride Absorption due to Ingestion of professionally Applied Gels
}

\author{
${ }^{1}$ Andreany M Cavalli, ${ }^{2}$ Adriana G Rebouças, ${ }^{3}$ Luciane Zanin, ${ }^{4}$ Flávia M Flório
}

\begin{abstract}
Aims: The aim of this study is to assess the influence of eating, prior to application of professionally used gels, on the rate of fluoride absorption due to the ingestion of $1.23 \%$ acidulated phosphate fluoride (APF).
\end{abstract}

Materials and methods: After fasting for 12 hours, 16 adult volunteers (>65 kg) ingested two types of meal: Breakfast $(n=8)$ and Lunch $(n=8)$. Accidental ingestion of fluoride gel used in molding trays was simulated (12,300 ppm; $61.5 \mathrm{mg} \mathrm{F} ; \mathrm{pH}=4.65)$ 15 minutes after eating. After ingestion of the fluoride solution, $3 \mathrm{~mL}$ of venous blood were collected at the following times: Zero (before ingestion) and 15, 30, 45 minutes, 1, 2, and 3 hours. Fluoride concentrations in blood plasma were determined using an ion selective electrode.

Results: With the exception of time $0(p>0.05)$, the average blood plasma concentration of the breakfast group (BG) $(0.34 \pm 0.04 \mathrm{mg} / \mathrm{L})$ was higher than that of the lunch group (LG) $(0.24 \pm 0.03 \mathrm{mg} / \mathrm{L})$, with the moment of peak concentration being 2 hours after ingestion for both groups (BG $=0.4 \mathrm{mg} / \mathrm{L}$; $\mathrm{LG}=0.28 \mathrm{mg} / \mathrm{L})$.

Conclusion: Results reinforce the idea that eating before undergoing professional application of fluoride is a factor of extreme importance regarding its safety, and that the time following a patient's heaviest meal should be the time of choice for planning clinical care.

Clinical significance: Our results should be considered when planning collective action that involves the application of the

\footnotetext{
1,2,4 Department of Public Health, São Leopoldo Mandic School of Dentistry and Research Center, Campinas, São Paulo Brazil

${ }^{3}$ Department of Public Health, Jundiaí Medical School, Area of Public Health, Jundiaí, Center University Hermínio Ometto de Araras, School of Dentistry, Araras, São Paulo, Brazil

Corresponding Author: Flávia M Flório, Professor, Department of Public Health, São Leopoldo Mandic School of Dentistry and Research Center, Campinas, São Paulo, Brazil, Phone: +19999087533, e-mail: flaviaflorio@yahoo.com
}

gel on children in a school environment, thus ensuring the procedure's safety.

Keywords: Children, Clinical trial, Fluoride, Safety, Topical fluoride gel.

How to cite this article: Cavalli AM, Rebouças AG, Zanin L, Flório FM. Assessment of the Influence of Meal Type on Fluoride Absorption due to Ingestion of professionally Applied Gels. J Contemp Dent Pract 2016;17(6):451-456.

Source of support: Nil

Conflict of interest: None

\section{INTRODUCTION}

Fluoride gel is one of the most widely used professional dental products in clinical practice, having been endorsed for use on individual and collective levels by the National Oral Health Policy and by international associations, such as the American Dental Association and the American Academy of Pediatric Dentistry, and its clinical efficiency has been demonstrated in controlled studies. ${ }^{1-6}$

Its clinical use is important for treating tooth decay; however, it may pose risks when accidentally ingested due to the high concentration of fluoride in products used professionally. ${ }^{5,7}$ In this regard, knowledge of the ion's mechanism of action and its toxic levels on the human body is essential for the safe handling of these compounds. ${ }^{6,8}$

High-concentration products can be safely used with the following recommendations, such as using the minimum amount needed to cover the teeth, vertical position during application, using a suction system throughout the procedure, and expectoration for 30 seconds afterwards. ${ }^{9}$ There is little or no danger of systemic toxicity when products containing fluoride are used as recommended; however, these products are sometimes ingested in excessive quantities. ${ }^{9,10}$ 
An acute dose of fluoride that may cause systemic toxicity is $5 \mathrm{mg} / \mathrm{kg} .{ }^{9,11,12}$ Reports of acute intoxication due to ingestion of dental products are more common in young children and in children less than 6 years old. A potentially toxic dose may be attained due to their low average body weight, taking into account the concentration of the product used and the amount ingested, among other factors that influence absorption, such as stomach contents. ${ }^{7,9,10,13-18}$

The influence of eating before the use of fluorinated compounds has been assessed in previous studies, which evaluated the use of products with low fluoride concentrations, such as toothpastes and fluoride tablets, and have indicated that eating beforehand reduces fluoride absorption by $19 \%$ when the compounds are ingested after breakfast and by around 33\% after lunch. ${ }^{11,18-20}$

No studies were found in the literatures that assess the effects of stomach contents on the absorption of fluoride arising from the ingestion of professionally used products with high fluoride concentrations. The ingestion of fluoride gel after application, assuming removal or nonremoval of any excess with gauze, was assessed in just one study in which volunteers had fasted, and showed that this clinical precaution significantly reduced patients' chances of nephrotoxicity, as the peak blood plasma concentrations of fluoride ions varied between 330 and $2,180 \mathrm{ng} / \mathrm{mL}$ when the excess was not removed. ${ }^{21}$

Cases of severe systemic toxicity and death due to acute exposure are rare nowadays; however, the occurrence of toxic signs and symptoms are more frequent, with gastric symptoms, such as nausea, vomiting, and diarrhea being reported. ${ }^{9}$ In this sense, knowledge of the influence of meal type on fluoride absorption when high-concentration products are used may contribute to forming a basis for safety recommendations regarding the use of professional fluoride products.

\section{MATERIALS AND METHODS}

The study was approved by the Research Ethics Committee at the São Leopoldo Mandic School of Dentistry, Campinas, São Paulo, under opinion no. 542.807/2013.

\section{Sample Selection}

All participants, residents of the same town (Balsas, Maranhão, Brazil; which does not add fluoride to its public water supply) and weighing at least $65 \mathrm{~kg}$, received information regarding the nature and details of the study and gave written informed consent. The size of the sample was based on previous studies that used similar methodology. ${ }^{18,20,22}$
Sixteen $(\mathrm{n}=16)$ adult volunteers (between 18 and 42 years of age, 4 females and 12 males) participated in this study, which was analyzed and approved by the Research Ethics Committee at the São Leopoldo Mandic School of Dentistry.

Volunteers underwent medical examinations and reported in their medical histories that they did not have heart, liver, or kidney problems and were not using any medication.

\section{Stage of Preparation of the Participants}

The volunteers were instructed not to use fluoride solutions in the 7 days prior to the commencement of the study, and to use the nonfluoride toothpastes provided by the researcher (Malvatrikids Baby*; Laboratório Daudt Oliveira Ltda.).

All the stages of the study were carried out in clinical laboratories, with volunteers being assured supervision by the researcher and medical assistance if necessary. During the experimental phase (3 hours), volunteers could not eat or ingest any kind of liquid.

\section{Initial Procedures}

Drawn at random, the volunteers were split into two study groups according to the two different meal types: Breakfast Group (BG; $\mathrm{n}=8$ ) and Lunch Group (LG; $\mathrm{n}=8$ ).

After fasting for 12 hours, the volunteers simultaneously received meals based on those normally consumed in Brazil ${ }^{18}$ in accordance with the study group into which they were sorted:

- BG: French bread with 10 gm of margarine and $200 \mathrm{~mL}$ of coffee with milk (1:3);

- LG: Rice (170 gm), meat and potatoes (160 gm), and a lettuce, cucumber, and tomato salad (60 gm).

Fifteen minutes after the meals, a solution containing $5 \mathrm{~mL}$ of acidulated phosphate fluoride (APF) gel $(12,300$ ppm; $\mathrm{pH}=4.65 ; 61.5 \mathrm{mgF}$ ) diluted in $10 \mathrm{~mL}$ of distilled water was ingested by all the volunteers, simulating the accidental ingestion of the suggested amount for professional application of fluoride gel with molding trays. ${ }^{23}$

\section{Collection and Analysis of Fluoride in the Volunteers' Blood Plasma}

After ingesting the solution containing fluoride, $3 \mathrm{~mL}$ of venous blood were collected from each volunteer at the following times: 0 (before ingestion of the solution containing fluoride), 15, 30, 45 minutes, 1, 2, and 3 hours. Samples were then centrifuged at $16,000 \mathrm{rpm}$ for 10 minutes. The plasma was separated and kept refrigerated (between 2 and $8^{\circ} \mathrm{C}$ ) awaiting analysis. ${ }^{18,20}$ 
Fluoride concentrations in blood plasma were blindly and simultaneously determined for each volunteer and each measurement, 3 hours after the last blood sample collection, using an ion selective electrode. ${ }^{11,21,24}$

For potentiometric determination of the ions, calibration curves were drawn, using standard samples of sodium fluoride solution with concentrations varying from 0.05 to $0.5 \mathrm{ppm} \mathrm{F}$, using a NaF solution at 1,000 ppm $\mathrm{F}$ as the initial baseline. One milliliter of plasma was then added to one milliliter of buffer solution and the samples were then divided. ${ }^{25}$

At the end of the study, bottles of Simeco plus (LaboratóriosSupera Farma), containing aluminum hydroxide $(120 \mathrm{mg} / \mathrm{mL})$, magnesium hydroxide $(60 \mathrm{mg} / \mathrm{mL})$, and simethicone $(7 \mathrm{mg} / \mathrm{mL})$ were given to the volunteers to alleviate potential gastric symptoms. Of the 16 volunteers, seven reported of having used them.

\section{Statistical and Pharmacokinetic Analysis}

Computer software (PK Solutions, Summit Research Services, Montrose, CO, USA) was used to obtain the following parameters: $\mathrm{C}_{\max }$ : maximum concentration observed during the 3-hour study period; $\mathrm{T}_{\max }$ : the time at which $\mathrm{C}_{\max }$ occurred; and AUC0-3: the area beneath the blood plasma concentration time curve from 0 to 3 hours.

Inferential methods were applied after the assessment of the data regarding fluoride concentration over time, maximum fluoride concentration, time of maximum fluoride concentration, and area beneath the curve, to check if they satisfied the assumptions of normality and homogeneity of variance. For data regarding fluoride concentration over time, the two-factor repeated measures, analysis of variance (ANOVA) and a Tukey test, were carried out to separate the interaction. For the response variables, such as maximum concentration and area under the curve, unpaired Student's t-test was used. For data regarding maximum concentration time, the nonparametric Mann-Whitney U test was used, due to heterogeneity of variance. Statistical calculations were performed using the Statistical Package for the Social Sciences (SPSS) version 20 software, at a 5\% significance level.

\section{RESULTS}

Table 1 shows, for both groups, the relationship between the quantity of fluoride ion ingested $(61.5 \mathrm{mg})$ by volunteers' body weight.

\section{Concentration of Fluoride in the Blood and Peak Absorption Time}

One of the two-factor repeated measures, ANOVA, applied to the data on fluoride concentration over time, indicated significant interaction between the type of meal
Table 1: Relationship between volunteers' body weight and proportion of fluoride ion ingested

\begin{tabular}{|c|c|c|c|c|c|}
\hline \multicolumn{3}{|c|}{$B G$} & \multicolumn{3}{|c|}{$L G$} \\
\hline Volunteer & $\begin{array}{l}\text { Body } \\
\text { weight }(\mathrm{kg})\end{array}$ & $\mathrm{F} / \mathrm{kg}$ & Volunteer & $\begin{array}{l}\text { Body } \\
\text { weight }(\mathrm{kg})\end{array}$ & $\mathrm{F} / \mathrm{kg}$ \\
\hline 1 & 75.0 & 1.22 & 6 & 75.4 & 1.23 \\
\hline 2 & 74.8 & 1.22 & 7 & 73.9 & 1.20 \\
\hline 3 & 89.0 & 1.45 & 8 & 72.0 & 1.17 \\
\hline 4 & 74.0 & 1.20 & 9 & 74.0 & 1.20 \\
\hline 5 & 71.0 & 1.15 & 10 & 70.4 & 1.14 \\
\hline 11 & 65.5 & 1.07 & 12 & 68.0 & 1.11 \\
\hline 13 & 75.8 & 1.23 & 15 & 76.9 & 1.25 \\
\hline 14 & 82.6 & 1.34 & 16 & 79.3 & 1.29 \\
\hline BG average & 76.0 & 1.24 & LG average & 73.7 & 1.20 \\
\hline
\end{tabular}

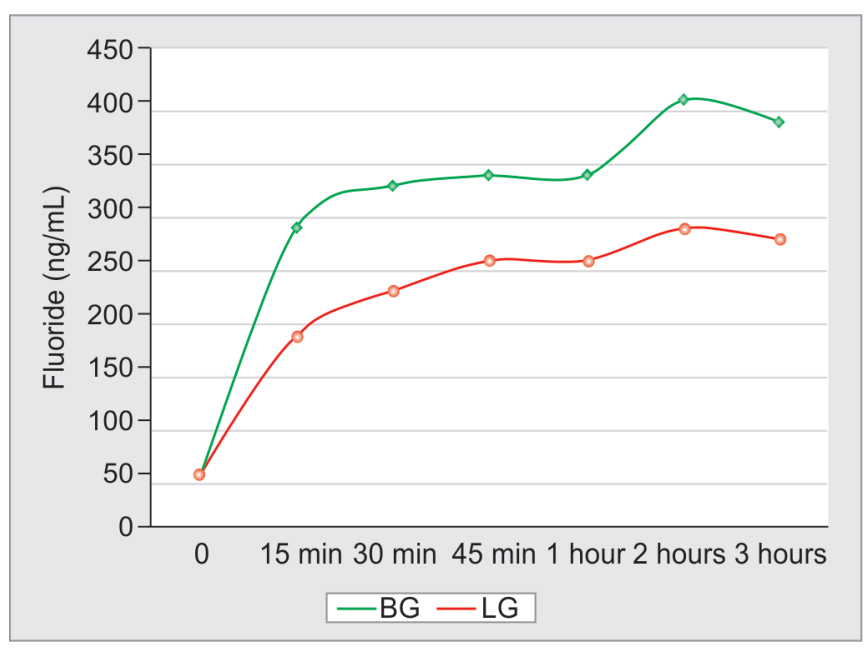

Graph 1: Concentrations of fluoride in blood plasma, measured in $\mathrm{ng} / \mathrm{mL}$, at the times of observation, for each study group

and the time elapsed after ingesting the gel $(\mathrm{p}<0.001)$, with a statistical power of 0.997 . Using the Tukey test, it was found that, with the exception of time 0 , at which point there was no significant difference between the fluoride concentrations measured in the volunteers' blood plasma, fluoride concentration was, at all times, significantly higher in the $\mathrm{BG}$, and was remaining so even after 3 hours ingestion (Graph 1).

Note that the time of maximum fluoride concentration in blood plasma (peak concentration) was not influenced by stomach content, as for both groups peak concentration was observed 2 hours after eating (Mann-Whitney U- test: $\mathrm{p}=0.674)$.

\section{Area Beneath the Blood- Time Concentration Curve}

The areas beneath the plasma concentration curves were calculated for each volunteer, taking into account the initial observation up until the final observation (last quantifiable concentration). The difference found in the 
area beneath the curve $(B G=61.69 \pm 0.42 \mu \mathrm{g}-\mathrm{min} / \mathrm{mL}$; $\mathrm{LG}=44.25 \pm 0.73 \mu \mathrm{g}-\mathrm{min} / \mathrm{mL}$ ) was significantly higher for the BG (Student's t-test, $p<0.001$ ). The reduction in fluoride absorption as a function of meal type was approximately $28.3 \%$.

\section{DISCUSSION}

The application of fluoride gel is a simple, practical method that is well accepted and is of low cost, with strong evidence of its inhibitory effects on tooth decay. ${ }^{4,26,27}$ It is considered a safe method with regard to acute toxicity, and the currently recommended procedure for professional application of APF gel minimizes the amount likely to be swallowed, minimizing the risk of even temporary stomach irritation. $4,23,28$

Professional application of fluoride gel is rarely performed on 1-year olds, but it is recommended for 2-year olds (average weight of $12.4 \mathrm{~kg}$ ). In these situations, if the molding trays are filled with the recommended limit of $5 \mathrm{~mL}$, then the potentially toxic dose in the eventuality of ingesting all the gel may be exceeded, causing at worst an upset stomach. ${ }^{9}$

In this study, the inclusion of healthy people with a minimum weight of $65 \mathrm{~kg}$ ensures complete safety for the volunteers, as the doses ingested were five times less than the potentially toxic dose. On the other hand, studies show that young animals are more resistant to the toxic effects of fluoride than adult animals, due to the higher rate of fluoride incorporation in the bones of the former, whose loosely organized and uncompressed bone crystals provide a much larger surface area for quick absorption of the ion. ${ }^{9}$ In this sense, the volunteers were under medical supervision throughout the study period and, although they reported nausea and abdominal discomfort, these symptoms were similar to those reported by participants in studies where the ingestion of toothpastes and residue of $1.3 \%$ acidulated fluoride gel was assessed. ${ }^{21,26,29}$ No volunteers abandoned the experiment or needed medical assistance during the study.

The assessment of fluoride absorption via blood plasma analysis enabled this study to indicate more sensitive results, as the pharmacokinetic curve of fluoride in saliva and in blood plasma has a ratio of 0.63:1. ${ }^{25,30-32}$

Dental surgeons must possess an adequate knowledge of the safety limits when performing high-concentration professional fluorotherapy. ${ }^{4,26}$ Its effects depend on stomach contents, and thus being important to monitor the period of time in order to reduce risks in case of accidental ingestion during professional fluoride application.

The means used in similar studies include a solution of fluoridated toothpaste containing 550 and 1,100 ppm of fluoride and $1.3 \%$ acidulated fluoride gel, with regard to parameters related to nephrotoxicity. ${ }^{18,21}$ No experiments were found in the literature that have determined fluoride absorption as a function of stomach contents, assuming the occurrence of accidental ingestion of gel during professional application.

A previous study involving the ingestion of residual fluoride gel after application, asking volunteers either to spit out or not to spit out the excess gel, showed higher blood plasma concentration values than those found in the present study. This is because the amount applied was $60 \%$ higher and, unlike the present study, volunteers were still fasting when the gel was applied. ${ }^{21}$ Eating prior to fully ingesting the gel ensured that, at no time during the study did blood levels indicate subclinical toxicity (>950 ng/mL). ${ }^{33}$ Only at the 2-hour mark did the BG show a value slightly higher $(400 \mathrm{ng} / \mathrm{mL})$ than that related to nephrotoxicity $(380 \mathrm{ng} / \mathrm{mL})$, which was offset by the fact that these values, which would have been adverse if maintained for more than 18 hours, were maintained for a short period of time. ${ }^{34}$

The type of meal did not influence the time of maximum fluoride concentration in blood plasma, which was 2 hours after eating, for both groups. This is probably due to the fact that the time of complete gastric emptying for liquids with low osmotic pressure is 2 hours. ${ }^{21,35,36}$ The difference was that, in the present study, peak concentration occurred after 2 hours, whereas in similar studies that involved APF gel and fasting volunteers, peak concentration occurred between 30 to 60 minutes. ${ }^{21}$

At time 0 , there was no difference in blood plasma fluoride concentration between volunteers from either group, which indicates that the volunteers' preparation was effective and the groups were homogenous regarding the parameters assessed. At the other times of observation, fluoride absorption was always higher in the $B G$, as can be observed in the literature concerning toothpaste ingestion. ${ }^{18}$

The reduction of fluoride absorption as a function of meal type was approximately $28.3 \%$ for the "lunch" meal type. Similar results were observed when comparing the bioavailability of ingested fluoride, in humans, in the form of NaF tablets $(2.21 \mathrm{mg})$ taken together with milk. ${ }^{19}$

Note that between 30 to 60 minutes after ingestion of the gel, blood plasma concentration in both groups remained constant and increased at the next point of observation. For the LG, at no time during the analysis was blood plasma concentration higher than that of the BG, suggesting that topical application of fluoride should be carried out up to 2 hours after heavy meals, because of the fact that the increase in concentration is related to gastric emptying.

It is worth noting that the meals offered to the volunteers, although typically consumed in Brazil, are 
not equivalent to meals eaten by a young child. Thus, the application of high-concentration products should follow all the recommendations already pointed out in the present study.

Therefore, this study reinforces the recommendation that high-concentration fluoride application should be performed only on individuals who have recently eaten, and its results should be considered when planning collective action that involves the application of the gel on children in a school environment, thus ensuring the procedure's safety.

\section{CONCLUSION}

Eating prior to the professional application of fluoride does influence fluoride absorption rates, thus being a factor of extreme importance, as it ensures the safety of the procedure even in cases of accidental ingestion. The period following the heaviest meal should be chosen when planning clinical care.

\section{CLINICAL SIGNIFICANCE}

Results reinforce the idea that eating before undergoing professional application of fluoride is a factor of extreme importance regarding its safety, and that the time following a patient's heaviest meal should be the time of choice for planning clinical care. Our results should always be considered when planning collective action that involves the application of the gel on children in a school environment; thus ensuring the procedure's safety.

\section{ACKNOWLEDGMENT}

Authors would like to thank the volunteers who took part in the study.

\section{REFERENCES}

1. Brasil. Ministério da Saúde. Secretaria de Atenção à Saúde. Departamento de Atenção Básica. Coordenação de Saúde Bucal. Política Nacional de Saúde Bucal. Diretrizes da Política Nacional de Saúde Bucal. Brasília; 2004.

2. ADA. American Dental Association Council on Scientific Affairs. Professionally applied topical fluoride evidencebased clinical recommendations. J Am Dent Assoc 2006 Aug;137(8):1151-1159.

3. AAPD. Guideline on Fluoride Therapy [online]. USA: American Academy of Pediatric Dentistry; 2014 [cited 2015 Mar 1]. Available from: http://www.aapd.org/media/ Policies_Guidelines/G_FluorideTherapy.pdf.

4. Almeida GJF, Yamamoto R, Corleto R, Fordel CB, Baldani $\mathrm{MH}$. Indicações de odontopediatras quanto ao uso de flúor tópico por crianças entre zero e seis anos de idade: dados para a elaboração de um protocolo de ações. Salusvita 2007;27(3):373-392.

5. Masson N, Domingues RR, Cury JA, Paes Leme AF. Acidulated phosphate fluoride application changes the protein composition of human acquired enamel pellicle. Caries Res 2013;47(3):251-258.

6. Marinho VC, Worthington HV, Walsh T, Clarkson JE. Fluoride varnishes for preventing dental caries in children and adolescents. Cochrane Database Syst Rev 2013 Jul 11; 7:CD002279.

7. Koparal E, Ertugrul F, Oztekin K. Fluoride levels in breast milk and infant foods. J Clin Pediatr Dent 2000 Summer;24(4):299-302.

8. Kobayashi CAN, Belini MR, Italiani FM. Factors influencing fluoride ingestion from dentifrice by children. Community Dent Oral Epidemiol 2011 Oct;39(5):426-432.

9. Whitford GM. Acute toxicity of ingested fluoride. Fluoride intake, metabolism and toxicity. In: Buzalaf MAR, editor. Fluoride and the oral environment. Monographs in Oral Science. Vol. 22. Basel, Switzerland: Karger; 2011. p. 66-80.

10. Whitford GM. Acute and chronic fluoride toxicity. J Dent Res 1992 May;71(5):1249-1254.

11. Ekstrand J, Spak CJ, Vogel G. Pharmacokinetics of fluoride in man and its clinical relevance. J Dent Res $1990 \mathrm{Feb} ; 69 \mathrm{Spec}$ No. 550-555; discussion 556-557.

12. Cury JA. Limitações do uso de fluoreto em Odontologia: toxicidade aguda e toxicidade crônica. J Assoc Bras Odontol 2009;(117):10-11.

13. Eichler HG, Lenz K, Fuhrmann M, Hruby K. Accidental ingestion of $\mathrm{NaF}$ tablets by children: report of a poison control center and one case. Int J Clin Pharmacol Ther Toxicol 1982 Jul;20(7):334-338.

14. Litovitz TL, Schmitz BF, Bailey KM. 1989 annual report of the American Association of Poison Control Centers National Data Collection System. Am J Emerg Med 1990 Sep;8(5):394-442.

15. Takase I, Kono K, Tamura A, Nishio H, Dote T, Suzuki K. Fatality due to acute fluoride poisoning in the workplace. Leg Med (Tokyo) 2004 Jul;6(3):197-200.

16. Guimarães AR, Modesto A, Vieira AR. Formation of alkalisoluble fluoride on the surface of human dental enamel after treatment with fluoridated gels: influence of the $\mathrm{pH}$ variation and of the treatment time. J Clin Pediatr Dent 2000 Summer;24(4):303-307.

17. Giacaman RA, Carrera CA, Muñoz-Sandoval C, Fernandez C, Cury JA. Fluoride content in toothpastes commercialized for children in Chile and discussion on professional recommendations of use. Int J Paediatr Dent 2013 Mar;23(2):77-83.

18. Cury JA, Fiol FSD, Tenuta LMA, Rosalen PL. Low-fluoride dentifrice and gastrointestinal fluoride absorption after meals. J Dent Res 2005 Dec;84(12):1133-1137.

19. Trautner K, Einwag J. Influence of milk and food on bioavailability from $\mathrm{NaF}$ an $\mathrm{Na}_{2} \mathrm{FPO}_{3}$ in man. J Dent Res 1989 Jan;68(1):72-77.

20. Shulman ER, Vallejo M. Effect of gastric contents on the bioavailability of fluoride in humans. Pediatr Dent 1990 Jul-Aug;12(4):237-240.

21. Sakata NY, Cury JA. Absorção de flúor e nefrotoxicidade após a aplicação tópica de gel. Rev Assoc Paul Cirur Dent 1987 Jan-Feb;41(1):57-89.

22. Montalli VA, Bergamaschi CC, Ramacciato JC, Nolasco FP, Groppo FC, Brito RB Jr, Haas DA, Motta RH. The effect of smoking on the bioavailability of metronidazole in plasma and saliva. J Am Dent Assoc 2012 Feb;143(2):149-156.

23. Ellwood R, Fejerskov O, Cury JA, Clarkson B. Fluoride in caries control. In: Fejerskov O, Kidd EA, editors. Dental caries. 
The disease and its clinical management. 2nd ed. Oxford: Blackwell Munksgaard; 2008. p. 287-323.

24. Paiva SM, Cury JA, Oliveira MJL, Martins CC, Tenuta LMA. Available fluoride in toothpastes used by Brazilian children. Braz Dent J 2010;21(5):396-400.

25. Ekstrand J. Fluoride concentrations in saliva after single oral doses and their relation to plasma fluoride. Scand J Dent Res 1977 Jan;85(1):16-17.

26. Ekambaram M, Itthagarun $A$, King NM. Ingestion of fluoride from dentifrices by young children and fluorosis of the teeth - a literature review. J Clin Pediatr Dent 2011 Winter;36(2):111-121.

27. Weyant RJ, Tracy SL, Anselmo T, Beltrán-Aguilar EJ, Donly KJ, Frese WA. Topical fluoride for caries prevention: executive summary of the updated clinical recommendations and supporting systematic review. J Am Dent Assoc 2013 Nov;144(11):1279-1291.

28. Whitford GM, Adair SM, Hanes CM, Perdue EC, Russell CM. Enamel uptake and patient exposure to fluoride: comparison of APF gel and foam. Pediatr Dent 1995 May-Jun;17(3): 199-203.
29. Lima YBO, Cury JA. A ingestão do flúor por crianças pela água e dentifrício. Rev Saúde Pública 2001;35(6):576-581.

30. Chae JW, Song BJ, Baek IH, Yun HY, Ma JY, Kwon KI. Effects of food intake on pharmacokinetics of mosapride in beagle dogs. J Vet Pharmacol Ther 2015 Oct;38(5):497-499.

31. Ostojic SM, Vojvodic-Ostojic A.Single-dose oral guanidinoacetic acid exhibits dose-dependent pharmacokinetics in healthy volunteers. Nutr Res 2015 Mar;35(3):198-205

32. Gabler WL. Absorption of fluoride through the oral mucosa of rats. Arch Oral Biol 1968 Jun;13(6):619-623.

33. Cousins MJ, Mazze RI. Methoxyflurane nephrotoxicity: a study of dose response in man. JAMA 1973 Sep 24;225(13):1611-1616.

34. Mazze RI, Calverley RK, Smith NT. Inorganic fluoride nephrotoxicity: prolonged enflurane and halothane anesthesia in volunteers. Anesthesiology 1977 Apr;46(4):265-271.

35. Roldi CR, Cury JA. Metabolismo de flúor após a ingestão de dentifrício. RGO Rev Gaúcha Odontol 1986 Sep-Oct;34(5):425-427.

36. Braz JRC, Castiglia YMM. Temas de anestesiologia: para o curso de graduação em medicina. 2nd ed. São Paulo: Unesp; Artes Médicas; 2000. 